\title{
Association between Constrictotermes cyphergaster (Silvestri, 1901) (Isoptera: Termitidae) with Pilosocereus gounellei (Weber ex Schum) Byles \& Rowley (Cactaceae) at the Northeastern Brazil
}

\section{Francisco de Assis da Silva1, Hélder Formiga Fernandes', Geuba Maria Bernardo da Silva ${ }^{2}$, Dimítri de Araújo Costa ${ }^{1}$, Martin Lindsey Christoffersen $^{3}$, Valdecir da Silva ${ }^{4}$, Gil Dutra Furtado ${ }^{5}$}

${ }^{1}$ Universidade Federal da Paraíba. Centro de Ciências Exatas e da Natureza. Programa de Pós-Graduação em Desenvolvimento e Meio Ambiente (PRODEMA). Cidade Universitária. João Pessoa-PB. Brazil (CEP 58051-900). E-mail: assismandela@gmail.com.

${ }^{2}$ Universidade Estadual da Paraíba. Centro de Ciências Biológicas e Sociais Aplicadas. Curso de Graduação em Relações Internacionais. Cristo Redentor. João Pessoa-PB. Brazil (CEP 58071-200).

${ }^{3}$ Universidade Federal da Paraíba. Centro de Ciências Exatas e da Natureza. Departamento de Sistemática e Ecologia. Programa de Pós-Graduação em Ciências Biológicas. Cidade Universitária. João Pessoa-PB. Brazil (CEP 58051-900).

${ }^{4}$ Universidade Federal da Paraíba. Departamento de Engenharia e Meio Ambiente. Curso de Graduação em Ecologia. Centro. Rio Tinto-PB. Brazil (58297-000).

${ }^{5}$ Faculdades de Enfermagem e Medicina Nova Esperança (FACENE/FAMENE). Valentina de Figueiredo. João Pessoa-PB. Brazil (CEP 58067-695).

Abstract. Termites are important components of tropical ecosystems, as decomposers and for their outstanding role in feeding guilds. There are about 2,800 species of termites in terrestrial ecosystems, organized into seven families. Factors that determine abundance in termite colonies are soil type, quality of microhabitat, humidity, and availability of food resources. The species Constrictotermes cyphergaster (Silvestri, 1901) belongs to the Family Termitidae and to the Subfamily Nasutitermitinae. Termites in this taxon are characterized by building their nests in arboreal environments and rocks. Ecological interactions of termites and cactaceans are still scarcely studied. The research was done during the year of 2014, at the Experimental Station of the Federal University of Paraíba, located in the Municipality of São João do Cariri, State of Paraíba, Brazil. A quadrant with a total area of 2,500 $\mathrm{m}^{2}$ was delimited. Fifteen random samples of Pilosocereus gounellei (Weber ex Schum) Byles \& Rowley containg termites, and 15 random samples without termites, were chosen. We report a previously unreported relationship between these organisms, and analize the relationship existing between the size of the cactaceans and the occurrence of termite mounds. We conclude that the relationship between the cactacean P. gounellei and the termite $C$. cyphergaster is one of herbivory of the later over the former. After consuming all the living tissues of the plants, the termites abandon the plant, because these cactaceans no longer
Recebido:

03/09/2017

Aceito:

09/11/2017

Publicado:

$31 / 12 / 2017$

Acesso aberto Artigo completo

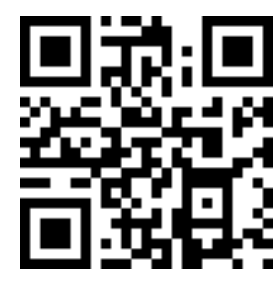

ORCIID

(D) $0000-0003-4329-1672$ Francisco de Assis da Silva 
provides the necessary conditions for the survival of termites. Xiquexique associated with termite mounds show visual signs of suffocating debilitation, leading to the total collapse of the cactaceans.

Keywords: Caatinga; Termite mounds; Xique-xique.

Resumo. Associação entre o cupim Constrictermes cyphergaster (Isoptera: Termitidae) com Pilosocereus gounellei (Weber ex Schum) Byles \& Rowley (Cactaceae) no Nordeste do Brasil. Os cupins ou térmitas tem grande a importância nos ecossistemas tropicais por seu papel nos processos de decomposição e sua posição na cadeia alimentar. Existem cerca de 2.800 espécies de cupins em ecossistemas terrestres, organizados em sete famílias. O tipo de solo, a qualidade do microambiente, a umidade e a disponibilidade de recursos alimentares influenciam na abundância das colônias dos térmitas. Constrictotermes cyphergaster (Silvestri, 1901) pertence à Família Termitidae e à Subfamília Nasutitermitinae. Os cupins destes grupos são caracterizados por construir seus ninhos em ambientes arborícolas e em rochas. As pesquisas sobre a relação ecológica entre cupinzeiros e cactáceas ainda são bastante escassas. A pesquisa foi realizada no ano de 2014, na Estação Experimental da Universidade Federal da Paraíba, localizada no Município de São João do Cariri, estado da Paraíba, Brasil. Foi delimitado um quadrante com área de $2.500 \mathrm{~m}^{2}$. Foram escolhidos de forma aleatória 15 pontos nos quais se encontravam o xique-xique Pilosocereus gounellei (Weber ex Schum) Byles \& Rowley com cupinzeiro e 15 sem o termiteiros. Estamos registrando uma relação anteriormente não relatada entre esses organismos, e analisamos a relação existente entre o tamanho das cactáceas e a ocorrência dos termiteiros. Concluímos que a relação entre o cupim C. cyphergaster e a cactácea $P$. gounellei é um tipo de herbivoria. Depois de consumir todos os tecidos vivos das plantas, os cupins abandonam a planta, porque essas cactáceas já não fornecem as condições necessárias para a sobrevivência destes. Os xique-xique associados com os termiteiros mostram sinais visuais de debilitação sufocante, levando ao colapso total das cactáceas.

Palavras-chave: Caatinga; Termiteiros; Xique-xique.

\author{
D) $0000-0002-0370-0673$ \\ Hélder Formiga \\ Fernandes \\ (1) 0000-0002-3698-6073 \\ Geuba Maria Bernardo \\ da Silva \\ (ㄱ) 0000-0002-5399-2483 \\ Dimítri de Araújo Costa \\ (ㄱ) 0000-0001-8108-1938 \\ Martin Lindsey \\ Christoffersen \\ (1) 0000-0002-7354-854X \\ Valdecir da Silva \\ (1) 0000-0001-5611-4814 \\ Gil Dutra Furtado
}

\section{Introduction}

Termites are important components of tropical ecosystems, as decomposers and for their outstanding role in feeding guilds (Coles, 1980). In many tropical ecosystems, termites dominate the landscape with their nests and termite mounds. They often surpass almost all other insect groups in numbers of individuals and biomass (Bandeira and Vasconcellos, 1999).

According Constantino and Acioli (2006), there are about 2,800 species of termites in terrestrial ecosystems, organized into seven families and the Families
Termitidae, Serritermitidae, Kalotermitidae, and Rhinotermitidae are reported in Brazil. Factors that determine abundance in termite colonies are soil type, quality of microhabitat, humidity, and availability of food resources (Constantino and Acioli, 2006).

Constrictotermes cyphergaster (Silvestri, 1901) belongs to the Family Termitidae and to the Subfamily Nasutitermitinae. Termites in this taxon are characterized by building their nests in arboreal environments and rocks. They inhabit Argentina, Bolivia, Brazil, and Paraguay (Constantino, 1999; Torales et al., 
2005; Lucena, 2016). According to Bandeira et al. (2007), C. cyphergaster feeds almost exclusively on wood (e.g., trunks, twigs, and branches). In some cases, these may include other types of available vegetation, such as cactuses and bromeliads.

The Cariri Region in the State of Paraíba is inserted in the Caatinga Biome. This formation presents 396 species of plants, organized into 90 families. Ten of these belong to the Cactaceae (Barbosa et al., 2007). The cactaceans occurring in this region are xerophilous and similar to the crassulaceans regarding water economy (Barreto and Barbosa, 2001). These families are very resistent in dry climates. Being well adapted to the semiarid region, they become important as food sources for animals, mainly during period of drough (Campos et al., 2017).

Ecological interactions of termites and cactaceans are still scarcely studied (e.g. Marín et al., 2004; Silva, 2014). However, among ecological relations established between thermites and plants, the following have been recognized: (1) a harmonic but indifferent relationship, when the host plant furnishes mechanical support, without being otherwise affected by the presence of these insects (Cesar et al., 1986); (2) a non-harmonic or negative relationship, when the termites damage the plant species (Cesar et al., 1986), usually by feeding on certain plant tissues (Lee and Wood, 1971); and (3) a harmonic or positive relationship, when the plants benefit from the presence of the termite mounds (Cesar et al., 1986). Additionally, we may relate the negative indirect impact caused by termites, which may modify some proprieties of the soil, that will influence the development of plant species (Cesar et al. 1986).

The cactaceans Pilosocereus gounellei (Weber ex Schum) Byles \& Rowley inhabits the Region of Caatinga, at Northeast Brazilian, on shallow, rocky or sandy soils (IUCN Red List, 2017).

The hypotheses in this paper are (1) termites of the species $C$. cyphergaster are potential herbivores of the cactacean "xique-xique"; (2) termites of this species prefer cactaceans of larger perimeter; (3) the field methods used in the present paper are efficient for analyzing relationships between termites and cactaceans.

So, the aim of the present study is to evaluate the heterotypic relationship between termites and "xique-xique" in the Municipality of São João do Cariri, State of Paraiba, Northeastern Brazil.

\section{Material and methods}

\section{Study area}

The research was done during the year of 2014, at the Experimental Station of the Federal University of Paraiba, located in the Municipality of São João do Cariri. The area is located within the Caatinga Biome, in the Semiarid Region of the State of Paraíba, Northeastern Brazil. This region belongs to the Planalto da Borborema, between the coordinates of $7^{\circ} 23^{\prime} 30^{\prime \prime} \mathrm{S}$ and $36^{\circ} 31^{\prime}$ 59" W (Figure 1). The altitude varies from 400 to $600 \mathrm{~m}$ above sea-level (Araujo et al., 2013). Soil types are Neossolo Lítico, Vertissolo and Luvissolo Crômico Vértico (Chaves et al., 2000). This region is characterized by semi-arid climate (Couto et al., 2015).

A quadrant with a total area of 2,500 $\mathrm{m}^{2}$ was delimited. Fifteen random samples of $P$. gounellei containg termites, and 15 random samples without termites, were chosen (Figure 1).

\section{Data collecting}

The perimeters of the termite mounds and of the cactaceans were measured, using the following formula: $\mathbf{P}=\mathbf{2} \times \boldsymbol{\pi} \times \mathbf{r}$, in which $\mathbf{P}$ is the Perimeter, $\boldsymbol{\pi}$ corresponds to the value of $\mathrm{Pi}(\cong 3,14)$, and $\mathbf{r}$ refers to the radius of the circle.

The activity in the termite mound was analized, being classified into Active and Inactive. In Active mounds the presence of termites was noted, while Inactive mounds did not show signs of the presence of termites.

Cactaceans with termite mounds were classified into Stage 1 plants (living plants), with less than $50 \%$ of the plant surface covered by the termite mound, Stage 2 plants (debilitated plants), with more than $50 \%$ of the plant surface covered 
by the termite mound, and Stage 3 plants (dead plants), for rotting plant individuals with virtually the whole surface covered by the termite mound.
For the analysis of $\mathrm{pH}$, tem soil samples containing cactaceans were collected, five of which contained termite mounds and five without mounds.

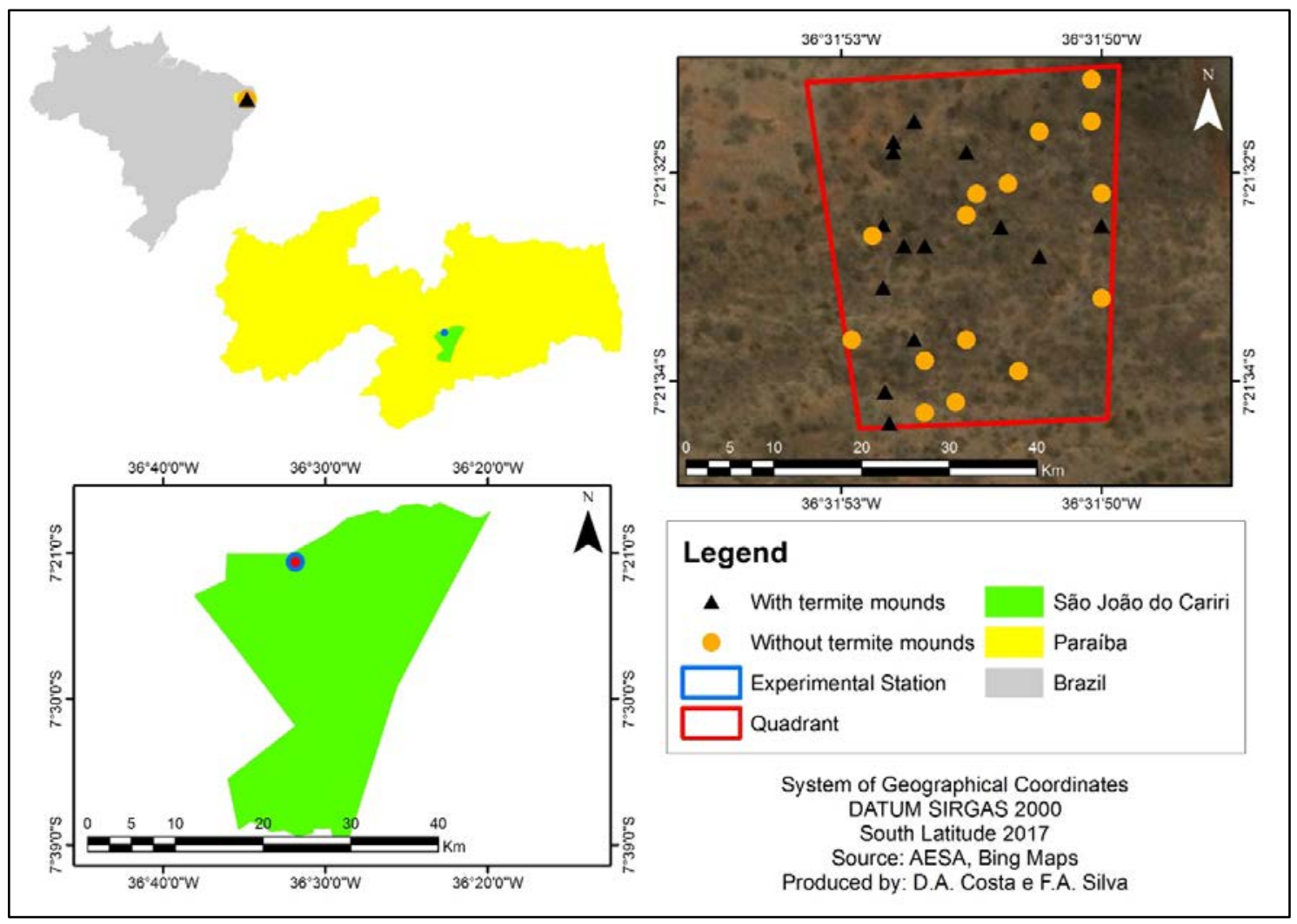

Figure 1. Map indicating the location of samples at Experimental Station of the Federal University of Paraiba, Municipality of São João do Cariri, State of Paraiba.

Excursions to the collecting site were made both during the day and night. Termites are nocturnal. Soldiers of this species collect food and also defend their termite mounds during the night (e.g. Moura et al., 2006).

In order to capture termites, mounds were sectioned longitudinally with a machete during daytime. Sections were 5 $\mathrm{cm}$ deep and $10 \mathrm{~cm}$ long. Termites were then captured with entomological pincers. Termites were preserved in alcohol at $70 \%$. They were identified under an Olympus stereomicroscope with the identification key of Constantino (1999), and the species was confirmed based on Cunha et al. (2015).

Soil samples were dried at environmental conditions, fragmented, processed, and then analized at Laboratório de Ecologia Química (LEQ), Universidade Federal da Paraíba, according to the norms of "Empresa Brasileira de Pesquisa Agropecuária” (EMBRAPA, 1997). Chemical analyses for evaluation of soil fertility and soil acidity $(\mathrm{pH})$ were conducted.

Statistical analyses were performed with programs PAST (Hammer et al., 2001) and R (R Development Core Team, 2011). 


\section{Results and discussion}

In the present study we detected a strong presence of termite mounds in the local cactaceans (xique-xique), corroborating the possible preference of termites for this species of plant (Figure 2).
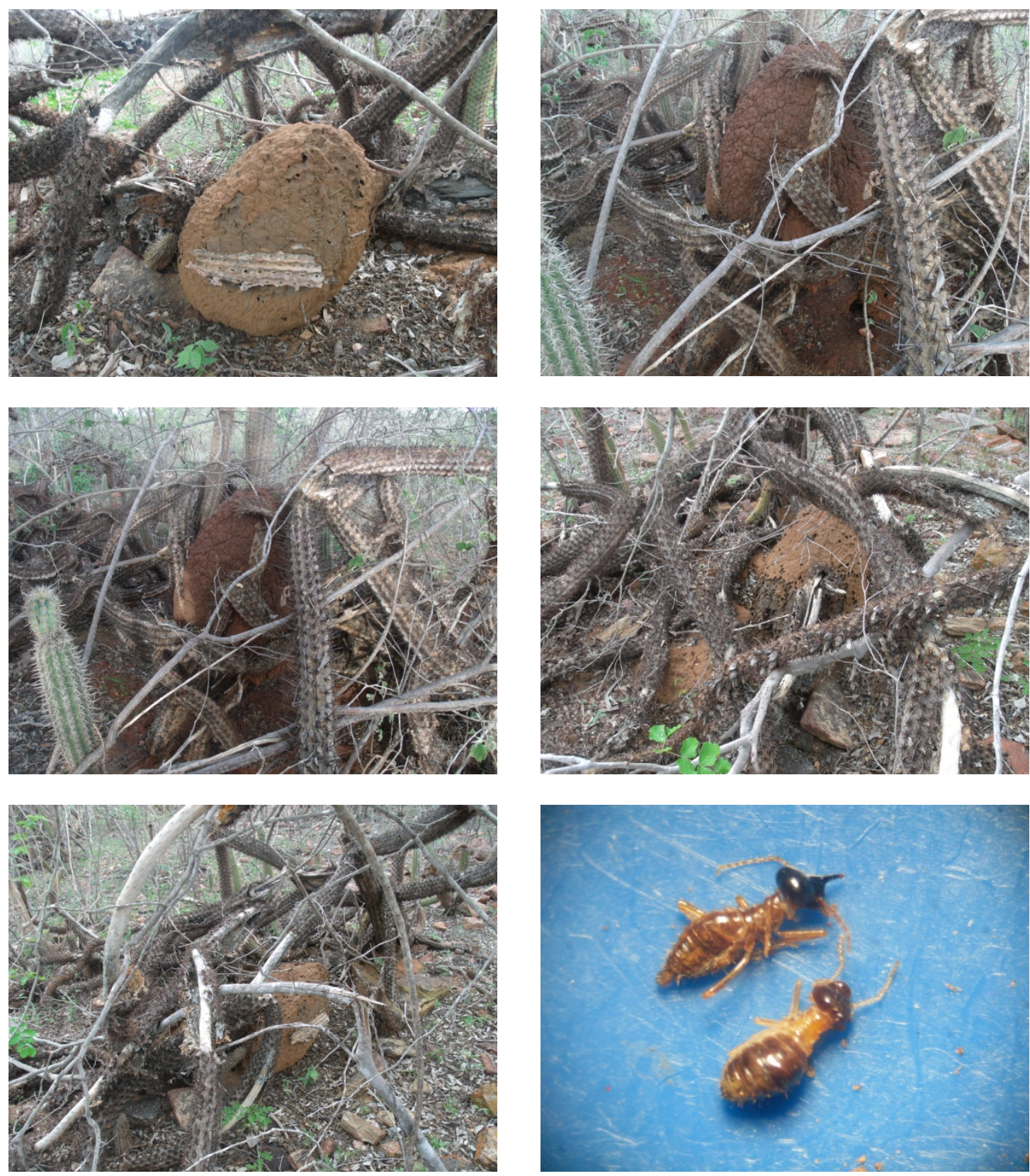

Figure 2. Xique-xique cactaceans with a termite mound of C. cyphergaster.

A total of $67 \%$ of termite mounds occurring on xique-xique were inactive (Figure 3).
We quantified $33 \%$ in Stage I (living), and 20\% in Stage II (debilitated) and $47 \%$ of cactaceans as in Stage III 
(dead) (Figure 4). We recorded most inactive termite mounds as occurring in Stage III (dead) cactaceans. This demonstrates that, after consuming all the living tissues of the plants, the termites abandon the plant, because these cactaceans no longer provides the necessary conditions for the survival of termites.

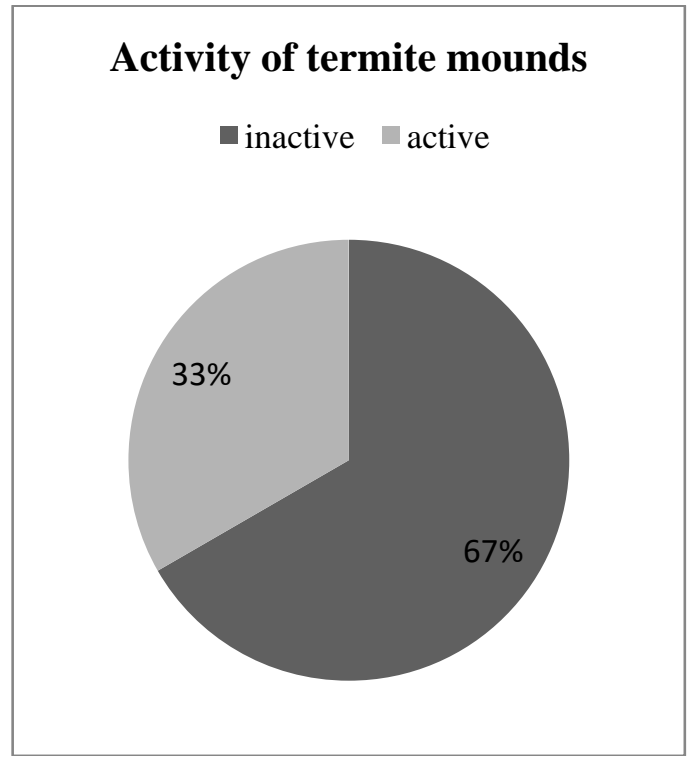

Figure 3. Proportion of active and inactive termite mounds.

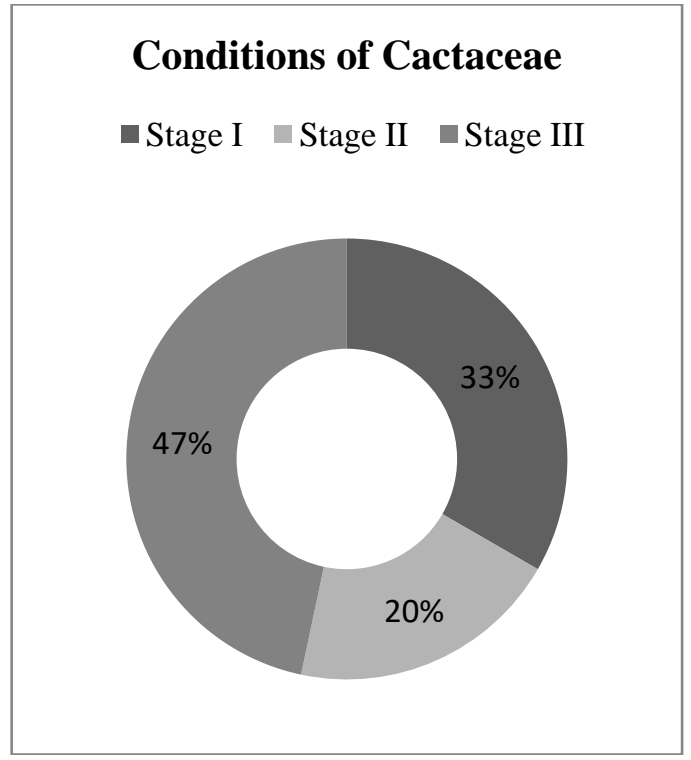

Figure 4. Proportion of Stage I (living), Stage II (debilitated), and Stage III (dead) cactaceans.

The experiments indicated that mean $\mathrm{pH}$ in soil containing healthy cactaceans and cactaceans with termite mounds is 6.9 and 6.4, respectively (Table $1)$. We may conclude that soil containing cactuses with termites is more acid relative to soils containing only cactaceans.

Table 1. Mean pH in soil samples with healthy cactaceans and with termite mounds in Estação Experimental, Bacia Escola de São João do Cariri.

\begin{tabular}{lcc}
\hline & Healthy cactaceans & Cactaceans with termite mounds \\
\hline Sample 1 & 7.05 & 6.2 \\
Sample 2 & 6.16 & 6.42 \\
Sample 3 & 6.63 & 6.24 \\
Sample 4 & 6.68 & 6.27 \\
Sample 5 & 7.87 & 7.06 \\
\hline Mean & $6.9 \pm 0.64$ & $6.4 \pm 0.34$ \\
\hline
\end{tabular}

We recorded that the mean perimeter of xique-xique with termites is larger than those without termites, $11.93 \mathrm{~m}$ $( \pm 4.11 \mathrm{~m})$ and $4.38 \mathrm{~m}( \pm 2.33) \mathrm{m}$, respectively (Figure 5). The Test of Shapiro-Wilk indicated that cactaceans without termites do not present normal distribution ( $\mathrm{W}=0.842, \mathrm{p}=0.0134)$. On the other hand, for plants with termites, the data are normal $(\mathrm{W}=0.9597, \mathrm{p}=0.6868)$. As the set of data are not parametric, we conducted the Wilcoxon Test. We found a significant difference between the perimeters of xique-xique with and without 
termites $\left(\mathrm{W}=120, \mathrm{p}=6.5331 \times 10^{-4}\right)$. The data reveal that termites prefer larger plants. These provide more food and furnish better structural conditions for the building of the mounds.

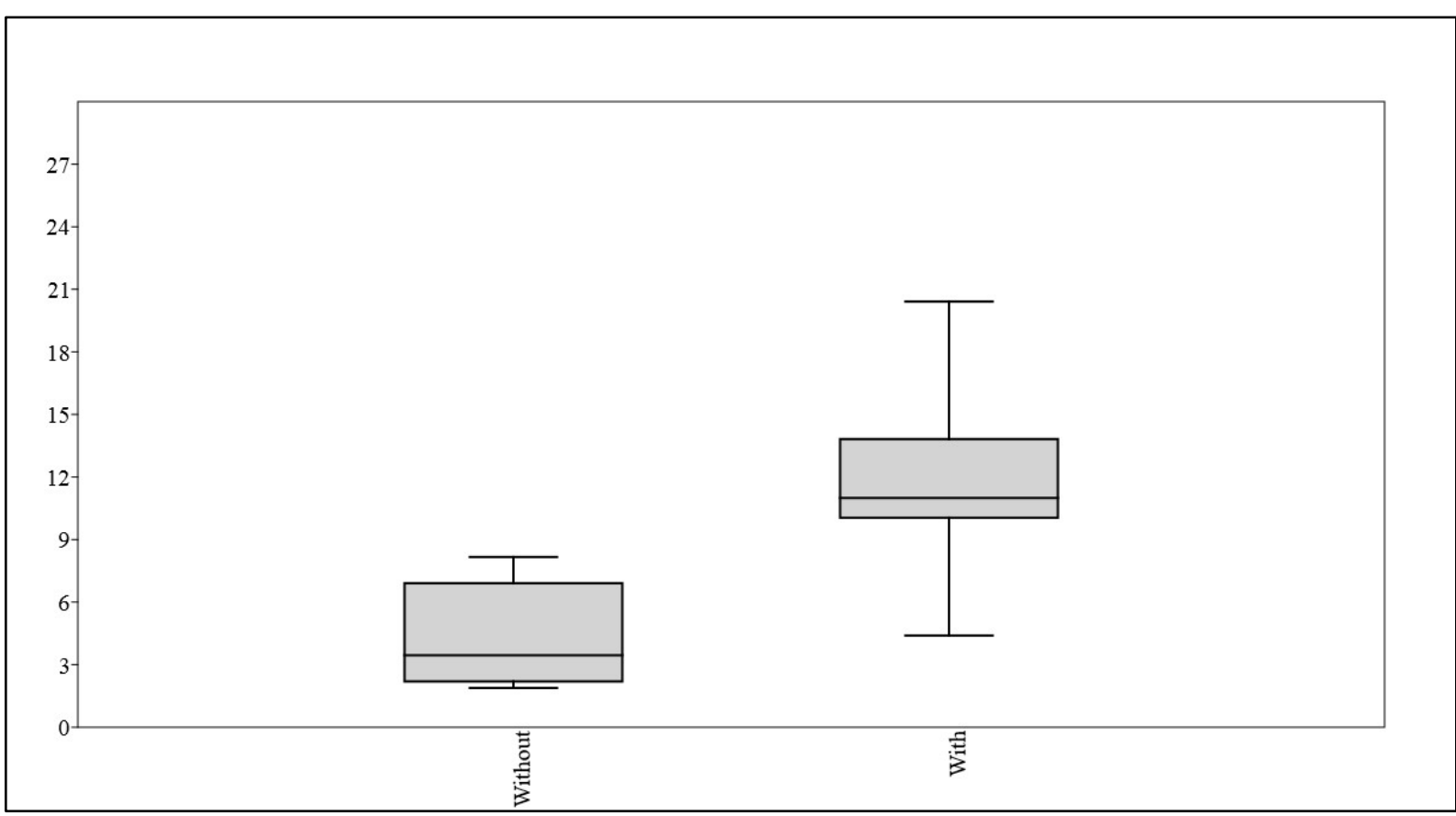

Figure 5. Perimeter of xique-xique without and with termites.

Similar results were described by Lima-Ribeiro et al. (2006), who associated C. cyphergaster with arboreal species in the Cerrado formation. Gonçalves et al. (2005) find that in the Atlantic Forest the presence of termites in trees is positively related to the size of the trees.

Finally, the perimeters of the cactaceans were correlated to the perimeter of the termite mounds. The Test of ShapiroWilk indicated that the data present normal distribution, both for the variable "vegetal" ( $W=0.9597, \quad p=0.6868)$, and for the variable "termite mound" ( $\mathrm{W}=0.9568$, $\mathrm{p}=0.6378$ ). The Pearson's Correlation indicated a significant positive correlation $(r=0.542, p<0.05)$ between the perimeters of xique-xique and of termite mounds (Figure 6). Thus, the bigger the cactacean, the bigger will be the termite mound.

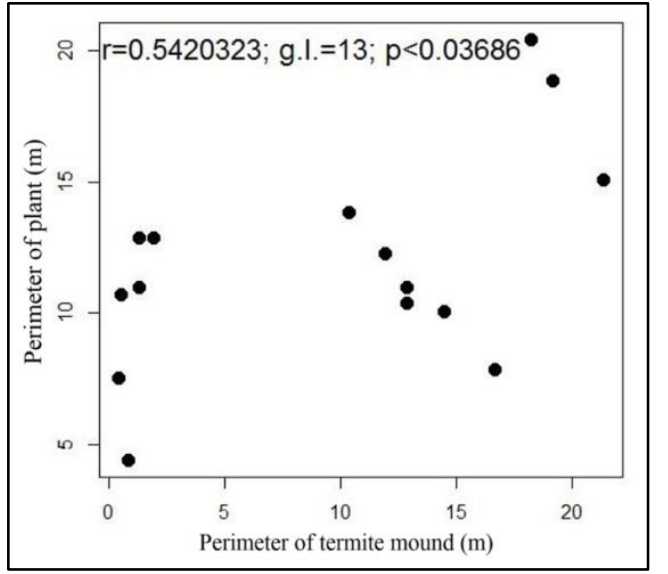

Figure 6. Pearson's Correlation between the perimeter of the cactacean Pilosocereus gounellei and the termite mound. 


\section{Conclusions}

The relationship between the cactacean $P$. gounellei and the termite C. cyphergaster is one of herbivory of the later over the former. Xique-xique associated with termite mounds show visual signs of suffocating debilitation, leading to the total collapse of the cactacean.

We suggest that this species of termite presents a case of adaptive feeding, in which the termites show preference for larger cactaceans. Large cactaceans provide a better source of food for the termites and better mechanical support for the construction of their mounds.

The field work used in this study was sufficient for testing the above hypotheses and was successful for reaching novel ecological results pertaining to the interactions of termites and cactaceans.

\section{Acknowledgements}

We thank Profs. Évio de Melo, Nadjacleia Almeida and Zelma Quirino, who lectured in the course Field Ecology, at Federal University of Paraiba, Campus IV, Municipality of Rio Tinto, State of Paraiba. We acknowledge the facilities of Federal University of Paraiba, Campus II, extended to the authors at Experimental Station, Municipality of São João do Cariri, State of Paraiba. Special thanks are due to Prof. Dr. Évio de Melo, who provided the Ecological Chemistry Lab (LEQ/UFPB-Campus IV) for the chemical analyses of soil samples.

\section{Conflicts of interest}

Authors declare that they have no conflict of interests.

\section{References}

Araujo, K. D.; Dantas, R. T.; Andrade, A. P.; Parente, H. N.; Pazera Júnior, E. Dinâmica da mesofauna edáfica em função das estações seca e chuvosa em áreas de caatinga sob pastejo. Brazilian Geographical Journal: Geosciences and Humanities Research Medium, v. 4, no. 2, p. 663-679, 2013. Available from: <http://www.seer.ufu.br/index.php/braziliangeoj ournal/article/view/23314>. Accessed on: 23 Jul. 2017.

Bandeira, A. G.; Pereira, J. C. D.; Miranda, C. S.; Medeiros, L. G. S. Composição faunística de cupins (Insecta, Isoptera) em área de Mata Atlântica em João Pessoa, Paraíba. Brasil. Revista Nordestina de Biologia, v. 12, no. 1/2, p. 9-17, 1998.

Bandeira, A. G.; Vasconcellos, A. Estado atual do conhecimento sistemático e ecológico sobre os cupins (Insecta, Isoptera) do nordeste brasileiro. Revista Nordestina de Biologia, v. 13, no. 1/2, p. 37-45, 1999.

Barbosa, M. R. V.; Lima， I. B.; Lima， J. R.; Cunha, J. P.; Agra, M. F.; Thomas, W.W. Vegetação e flora no Cariri Paraibano. Oecologia Brasiliensis, v. 11, no. 3, p. 313-322, 2007.

Barreto, A. F.; Barbosa, J. K. A. Mecanismos de resistência à seca que possibilitam a produção em condições do semi-árido nordestino. Anais do III Simpósio Brasileiro de Captação de Água de Chuva do Semi-Árido, 2001.

Campos, F. S.; Gois, G. C.; Vicente, S. L. A.; Macedo, A.; Matias, A. G. S. Alternativa de forragem para caprinos e ovinos criados no semiárido. Nutri Time, v. 14, no. 2, p. 50045013, 2017. Available from: $<$ http://www.nutritime.com.br/arquivos_interno s/artigos/Artigo_416.pdf $>$. Accessed on: 23 Apr. 2017.

Cesar, H. L.; Bandeira, A. G.; Oliveira, J. G. B. Estudo da relação de cupins e seus ninhos com a vegetação de campos no Estado do Pará, Brasil. Boletim do Museu Paraense Emílio Goeldi, v. 2, no. 2, p. 119-139, 1986.

Chaves, L. H. G.; Chaves, I. B.; Vasconcelos, A. C. F. Salinidade das águas superficiais e suas relações com a natureza dos solos na Bacia Escola do Açude Namorados. Campina Grande: BNB/UFPB, 2000. (Boletim Técnico).

Coles, H. R. Defensive strategies in the ecology of Neotropical termites. Southampton: University of Southampton, 1980. (Doctorat Thesis).

Constantino, R. Chave ilustrada para identificação dos gêneros de cupins (Insecta: Isoptera) que ocorrem no Brasil. Papéis Avulsos de Zoologia, v. 40, no. 25, p. 387-448, 1999.

Constantino, R.; Acioli, A. N. S. Termite Diversity in Brazil. In: Moreira, F. M. S.; Siqueira, J. O.; Brussaard, L. (Orgs.). Soil biodiversity in Amazonian and other 
Brazilian ecosystems. Wallingford: CABI publishing, 2006. p. 117-128.

Couto, A. A. V. O.; Albuquerque, A. C.; Vasconcellos, A.; Castro, C. C. Termite assemblages (Blattodea: Isoptera) in a habitat humidity gradient in the Semiarid Region of Northeastern Brazil. Zoologia, v. 32, no. 4, p. 281-288, 2015. https://doi.org/10.1590/ S1984-46702015000400003

Cunha, H. F.; Lima, J. S.; Souza, L. F.; Santos, L. G. A.; Nabout, J. C. No morphometric distinction between the host Constrictotermes cyphergaster (Silvestri) (Isoptera: Termitidae: Nasutitermitinae) and its obligatory termitophile Corotoca melantho Schiødte (Coleoptera: Staphylinidae). Sociobiology, v. 62, no. 1, p. 65-69, 2015. https://doi.org/10.13102/ sociobiology.v62i1.65-69

EMBRAPA - Empresa Brasileira de Pesquisa Agropecuária. Manual de métodos de análise de solo. 2. ed. rev. atual. Rio de Janeiro: Centro Nacional de Pesquisa de Solos, 1997.

Gonçalves, T. T.; DeSouza, O.; Reis Jr., R.; Ribeiro, S. P. Effect of tree size and growth form on the presence and activity of arboreal termites (Insecta: Isoptera) in the Atlantic Rain Forest. Sociobiology, v. 46, no. 2, p. 421-431, 2005.

Hammer, Ø.; Harper, D. A. T.; Ryan, P. D. PAST: Paleontological statistics software package for education and data analysis. v. 3.13. Palaeontologia Electronica, v. 4, no. 1, 9 p., 2001. Available from: <http://palaeoelectronica.org/2001_1/past/issue1_01.htm>.

Accessed on: 23 Apr. 2017.

IUCN Red List. The IUCN Red List of Threatened Species. Available from: <http://www.iucnredlist.org/details/152327/0>. Accessed on: Mar. 17, 2017.

Lee, K. E.; Wood. T. G. Termites and soils. London: Academic Press, 1971.
Lucena, E. F. Variação temporal em instares de Constrictotermes cyphergaster (Isoptera, Termitidae) em Caatinga do Estado da Paraíba. Patos: Universidade Federal de Campina Grande, Paraíba, 2016. (Undergraduation monography).

Lima-Ribeiro, M. S.; Pinto, M. P.; Costa, S. S.; Nabout, J. C.; Rangel, T. F. L. V. B.; Melo, T. L.; Moura, I. O. Associação de Constrictotermes cyphergaster Silvestri (Isoptera: Termitidae) com espécies arbóreas do Cerrado Brasileiro. Neotropical Entomology, v. 35, no. 1, p. 49-55, 2006. https://doi.org/ 10.1590/S1519-566X2006000100007

Marín, I. V.; Escotto, H. C.; Santos, I. P.; Martínez, J. A. P.; Mainegra, A. B.; Isasi, N. T. Primeros registros de afectaciones en Dendrocereus nudiflorus (cactácea) en la reserva ecológica Varahicacos, Cuba. Revista Forestal Baracoa, v. 23, no. 2, p. 55-58, 2004.

Moura, F. M. S.; Vasconcellos, A.; Araújo, V. F. P.; Bandeira, A. G. Feeding habit of Constrictotermes cyphergaster (Isoptera, Termitidae) in an area of Caatinga, Northeast Brazil. Sociobiology, v. 48, p. 21-26, 2006.

R Development Core Team. R: A language and environment for statistical computing. Vienna: The R Foundation for Statistical Computing, v. 3.1.1, 2011. Available from: <http://www.Rproject.org>. Accessed on: Apr. 23, 2017.

Silva, F. L. Campos de Murundus da Bacia Hidrográfica do Rio Guaporé: caracterização pedológica e teores de elementos-traço. Cáceres: Universidade do Estado de Mato Grosso, 2014. (Master degree dissertation).

Torales, G. J.; Laffont, E. R.; Godoy, M. C.; Coronel, J. M.; Arbino, M. O. Update on taxonomy and distribution of Isoptera from Argentina. Sociobiology, v. 45, no. 3, p. 853886, 2005.

License information: This is an open-access article distributed under the terms of the Creative Commons Attribution License, which permits unrestricted use, distribution, and reproduction in any medium, provided the original work is properly cited. 